\title{
Compilation of Lessons Learned From the Analysis of Superfund
}
M. R. Siegel
J. A. Powell
C. W. Abrams

March 1991

Prepared for the U.S. Department of Energy under Contract DE-AC06-76RLO 1830

Pacific Northwest Laboratory Operated for the U.S. Department of Energy by Battelle Memorial Institute 


\title{
DISCLAIMER
}

This report was prepared as an account of work sponsored by an agency of the United States Government. Neither the United States Government nor any agency thereof, nor Battelle Memorial Institute, nor any of their employees, makes any warranty, expressed or implied, or assumes any legal liability or responsibility for the accuracy, completeness, or usefulness of any information, apparatus, product, or process disclosed, or represents that its use would not infringe privately owned rights. Reference herein to any specific commercial product, process, or service by trade name, trademark, manufacturer, or olherwise does not necessarily constitute or imply its endorsement, recommendation, or favoring by the United States Government or any agency thereof, or Battelle Memorial Institute. The views and opinions of authors expressed herein do not necessarify state or reílect those of the United States Government or any agency thereof.

\author{
PACIFIC NORTHWEST LABORATORY \\ operated by \\ BATTELLE MEMORIAL INSTITUTE \\ for the \\ UNITED STATES DEPARTMENT OF ENERGY \\ under Contract DE-ACO6-76RLO 1830
}

Printed in the United States of America

Available to DOE and DOE contractors from the

Office of Scientific and Technical Information, P.O. Box 62, Oak Ridge, TN 37831; prices available from (615) 576-8401. FTS 626-8401.

Available to the puhlic from the National Technical Intormation Service, U.S. Department of Commerce, 5285 Port Royal Rd., Springfield, VA 22161. 
COMPILATION OF LESSONS LEARNED

FROM THE ANALYSIS OF SUPERFUND

M. R. Siegel

J. A. Powell

C. W. Abrams

March 1991

Prepared for

the U.S. Department of Energy

under Contract DE-AC06-76RLO 1830

Pacific Northwest Laboratory

Richland, Washington 99352 


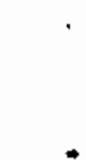




\section{EXECUTTVE SUMMARY}

The U.S. Department of Energy (DOE) is in the initial stages of its complex-wide environmental restoration program. This environmental resioration program is being conducted primarily under the statutory authorities of the Comprehensive Ervironmental Response, Compensation, and Liability Act (CERCLA) and the corrective action provisions of the Resource Conservation and Recovery Act (RCRA). Environmental restoration at DOE facilities is expected to be a multi-billion dollar effort extending over the next 20-50 years. DOE must take necessary steps, as required by federal and state statutes and regulations, to protect human health and the environment at those facilities and operations under its purview. DOE is obligated to carry out this mission in the most effective and cost-efficient manner possible, while still meeting or exceeding applicable regulatory requirements.

The U.S. Environmental Protection Agency (EPA) is the agency primarily responsible for administering CERCL.A EPA's implementation of the Superfund program has come under considerable scrutiny and criticism over its 10-year history. Many external groups have reviewed EPA's Superfund program, identified shortcomings or deficiencies, and made numerous recommendations for its improvement. The groups reviewing EPA's Superfund program include the Office of Technology Assessment (OTA), the General Accounting Office (GAO), and business and environmental organizations.

The purpose of this report is to identify the issues cited by these groups that are most relevant to DOE's environmental restoration program and to discuss the implications of the studies' findings for DOE. The findings of these groups are presented because they are representative of the areas where DOE will be scrutinized in the future. DOE does not necessarily agree with the findings and conclusions of these studies.

Many of the issues and shortcomings identified by these groups, such as problems related to use of enforcement powers, are relevant only to EPA. Numerous other issues, however, have a potential bearing on DOE's environmental resioration program. These issues include remedy selection for specific waste sites, selection of cleanup standards, the establishment of performance criteria, the use and development of innovative technologies, the use and management of contractors, streamlining of the CERCLA process, management and development of internal staff, and organizational issues.

The findings of the review groups can have a number of implications for DOE and, at a minimum, should serve as lessons learned. For example, a repeated finding was that EPA did not select cleanup remedies in a consistent manner, and a number of the groups noted that EPA lacked reievant criteria to measure its performance in remediating CERCLA sites. Another consistent criticism of EPA was its failure to utilize new and innovative technologies or its inappropriate use of technologies.

As DOE continues to implement its environmental restoration program, it can leam many lessons from EPA's experiences with CERCLA and the observations made by these external review groups. An awareness of the problems may help DOE avoid the same pitfalks and thereby increase the effecriveness and ultimate success of the environmental restoration program. Given the visibility of the program and the associated cost, it is inevitable that DOE's environmental restoration program will be as closely scrutinized as EPA's Superfund program. An awareness of the potential problem areas will help DOE avoid or identify deficiencies before they are discovered by the review groups following years of remediation work and large expenditures. This proactive stance to identify, assess, and avoid or minimize problem areas in the implementation of the environmental restoration program can both increase the effecriveness of the program and enhance DOE's credibility with Congress, regulators, and the public. 


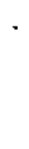




\section{CONTENTS}

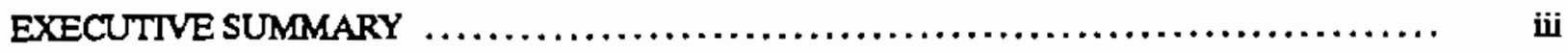

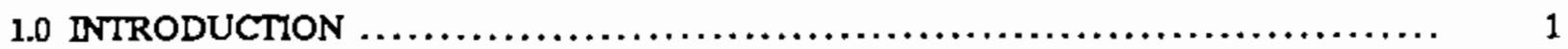

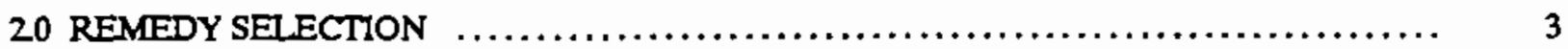

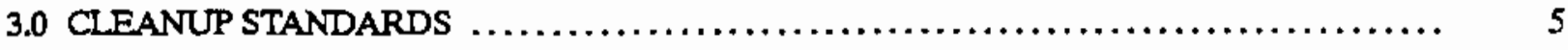

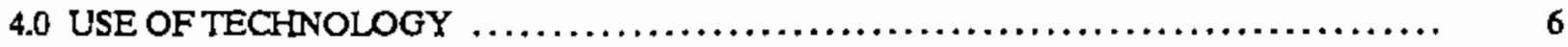

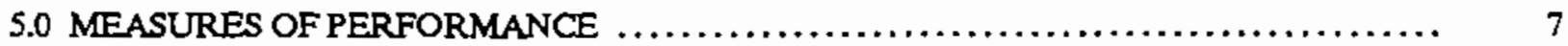

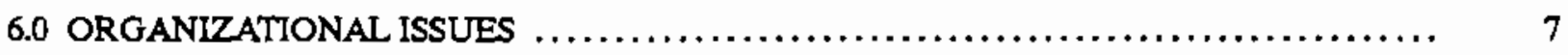

7.0 STREAMLINING OF THE CERCLA PROCESS $\ldots \ldots \ldots \ldots \ldots \ldots \ldots \ldots \ldots \ldots \ldots \ldots \ldots \ldots \ldots \ldots$

8.0 STAFF UTLIZATION AND DEVELOPMENT $\ldots \ldots \ldots \ldots \ldots \ldots \ldots \ldots \ldots \ldots \ldots \ldots \ldots \ldots \ldots$

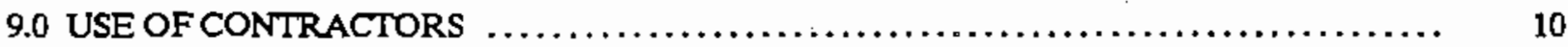

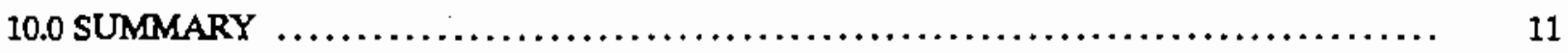

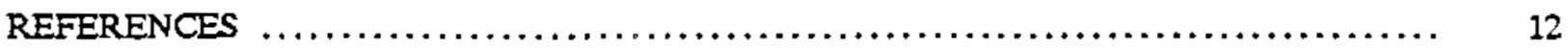


, 


\subsection{INTRODUCTION}

The Comprehensive Environmental Response, Compensation, and Liability ACt (CERCLA or Superfund) was enacted in 1980 in response to a recognition of a "hazardous waste crisis" and the apparent inadequacy of prior environmental laws to address this national problem. This original statute was relatively short compared with other environmental legislation, and much of its implementation was left to the U.S. Environmental Protection Agency (EPA). CERCLA was intended to establish a statutory framework to govern the cleanup of existing, and often abandoned, hazardous waste sites.

The history of the Superfund program between 1980-1986 was rather checkered This period was characterized by considerable controversy, much litigation, and reportedly limited progress in cieaning up the nation's hazardous waste sites. In response to the magnitude of the hazardous waste problem and general dissatisfaction with progress in implementing the Act, Congress amended CERCLA in 1986 through the passage of the Superfund Amendments and Reauthorization Act (SARA). Among other things, SARA clarified the federal government's enforcement powers ander CERCLA, made CERCLA clearly applicable to federal facilities, authorized a fund of $\$ 9$ billion for the cleanup of non-federal facilities, and expanded the scope and nature of health studies to be conducted at hazardous waste sites.

The perceived politicalization of CERCLA during the early 1980 s attracted considerable atuention to EPA's actions in the hazardous waste area. This heightened controversy surrounding EPA's CERCLA program has led to trequent reviews and analysis of EPA's efforts in this area. The U.S. General Accounting Office (GAO) and the Office of Technology Assessment (OTA), both investigative arms of Congress, have taken the lead in this area These offices have published studies critical of both EPA's overall Superfund program as well specific areas of the program. Industry and environmental groups have also been very active in assessing the Superfund program, identifying shortcomings, and suggesting necessary changes, both in the basic legislation and in EPA's implementation of CERCLA.

Despite questions regarding the relative impact on public health and the environment of hazardous waste siles, these reviews and assessments of the Superfund program continue, at least somewhat driven by the fact that CERCLA was scheduled to be reauthorized in 1991. (CERCLA was extended in October of 1990). The reports contain many conclusions and recommendations for the program's improvement As one might expect, the conclusions and recommendations made by one group are not necessarily consistent with those made by another group. Often, one group finds reasons to praise EPA's effons in the Superfund area, while another group takes EPA to task for the same effort Table 1 presents a summary of issues addressed by these studies.

The U.S. Department of Energy (DOE) is currently undertaking considerable environmental restoration activities at its facilities nationwide. DOE is committed to carrying out its operational functions in full compliance with applicable federal, state, and local environmental statutes and regulations. With respect to hazardous substances, this involves achieving compliance with both CERCLA and the Resource Conservation and Recovery Act (RCRA) and the corresponding state laws.

While considerable activity has already begun, DOE's ervironmental restoration program is gen. erally sill in its early and developmental stages. The great majority of affected DOE sites are either awaiting or undergoing site characterization. When addressing these sites, DOE risks encountering many of the same problems and difficulties EPA did when it implemented its CERCLA program. Accordingly, the DOE Office of Environmental Guidance, EH-23, with technical support from the 
Table 1. DOE-Relevant

Environmental Reports

(by subject matler)

\begin{tabular}{|c|c|c|c|c|c|c|c|c|}
\hline Report Tillin & $\mid \begin{array}{l}\text { Aemody } \\
\text { selectlon }\end{array}$ & $\begin{array}{c}\text { Cloanup } \\
\text { Slandards }\end{array}$ & $\begin{array}{l}\text { Use of } \\
\text { Tochnolody }\end{array}$ & \begin{tabular}{|l|} 
Moasures of \\
Portormance
\end{tabular} & $\begin{array}{c}\text { Organizational } \\
\text { Issues }\end{array}$ & $\begin{array}{l}\text { Stresmilning of } \\
\text { the CERCLA } \\
\text { Process }\end{array}$ & $\begin{array}{l}\text { Sloft Utilization } \\
\text { and Devalopment }\end{array}$ & $\begin{array}{c}\text { Use of } \\
\text { Cominetors }\end{array}$ \\
\hline $\begin{array}{l}\text { Letter to Lew Crampton Aegarding Supartund Program } \\
\text { Improvementach2MHнII }\end{array}$ & & & & & & $\bar{x}$ & $\mathbf{x}$ & $x$ \\
\hline $\begin{array}{l}\text { Superfund Contracts: EPA' Procedures for Preventing Conflet } \\
\text { of linterest Need Situnglhening/OAO }\end{array}$ & & & & & & & & $\mathbf{x}$ \\
\hline $\begin{array}{l}\text { Suporfund Contracts: EPA Natd to Control Coniractor } \\
\text { CostofoAO }\end{array}$ & & & & & & & & $x$ \\
\hline $\begin{array}{l}\text { Improving Romedy Seleclion: An Expllell and Interactlve } \\
\text { Procese for the Superfund PropramClion Siloe }\end{array}$ & $x$ & & & & & & & \\
\hline $\begin{array}{l}\text { Maklng Superfund Work: Fecommondatione to Improve } \\
\text { Program Implementellon/Clean Stles }\end{array}$ & $x$ & & $\mathbf{x}$ & $\mathbf{x}$ & $x$ & & $x$ & \\
\hline 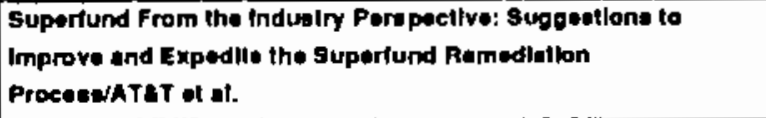 & $x$ & $x$ & & & $x$ & $x$ & $x$ & \\
\hline Treeking Superfund: Where the Progrem Stundetebf al al. & $\mathbf{x}$ & $\mathbf{x}$ & $x$ & & & & & \\
\hline Coming Clenn; Bupertund Problems Cen Bo Solved...JotA & $x$ & $\mathbf{x}$ & $x$ & $\mathbf{x}$ & $\mathbf{x}$ & & $x$ & $x$ \\
\hline $\begin{array}{l}\text { Supertund: Improvemente Naeded In Work Foree Manegement } \\
\text { aAO }\end{array}$ & & & & & & & $x$ & \\
\hline Are We Cloaning Up? to Supertund Case SludbeatoTA & $\mathbf{x}$ & & $x$ & & & & & \\
\hline $\begin{array}{l}\text { Cleaning up the Natlon's Clanup Program/Senate } \\
\text { Subcommitten on Superlund }\end{array}$ & & $x$ & $\mathbf{x}$ & & $x$ & $x$ & $\boldsymbol{x}$ & $x$ \\
\hline $\begin{array}{l}\text { Fight Train, Wrong Track: Falled Leadorthlp in the Supertund } \\
\text { Ciosnup Program/EDF al al. }\end{array}$ & $\mathbf{x}$ & $\mathbf{x}$ & $x$ & $x$ & & & & \\
\hline The Supertund Remedial Aelton Declalon ProcesefOAML. & $\mathbf{x}$ & $x$ & & & $x$ & & & \\
\hline Manapement of Suporfund/Commlltee on the Budgd & & & & $x$ & & & & $\mathbf{x}$ \\
\hline Kansogmenl Alovlow of the Supurfund Program/EPA & $x$ & & $\mathbf{x}$ & & $\mathbf{x}$ & & & $x$ \\
\hline
\end{tabular}


Pacific Northwest Laboratory (PNL), has en. deavored to identify and assess the relevance of these issues to DOE's implementation of its environmental restoration program.

A number of issues identified by these groups apply exclusively to EPA, such as EPA's implemensation of its enforcement authority against private parties. There are, however, a number of CERCL_A-related implementation issues that are common to both EPA and DOE For example, the organizational structures of EPA and DOE are roughly parallel. Over the years, EPA has been criticized for vesting too much decisionmaking authority in its regions with a resulting inconsistency in Superfund impiementation across the country. While DOE is moving toward instituting adequate controls to monitor activities at its field and operations offices, the comments regarding shorcomings of the EPA organizational structure are still highly relevant to DOE

Because of the high profile and anticipated costs, it is inevitable that Congress and environmental groups will closely scrutinize the implementation and efficiency of DOE's environmental restoration program over the coming years. It is vital that DOE learn from the 10 years' experience that EPA has had with the Superfund program. This will belp DOE identify issues before they become roadblocks to progress. DOE's performance and its credibility with the public, Congress, and regulators will be enhanced if it can demonstrate that it is not repeating the mistakes that EPA encountered years before in its CERCLA program and is otherwise conducting its environmental restoration program in a responsible manner. This report is intended to assist DOE in this effort.

This report focuses on eight key areas identified as problems for EPA for which there are parallels to DOE. These areas include measuring performance, remedy selection, establishing consistent cleanup standards, the use of new and innovative technologies, the use and management of contractors, streamlining of the CERCLA process, management and development of EPA staff, and EPA organizational issues. Other issues related to
EPA's regulatory functions, such as its enforcement authorities, though much criticized by the outside studies reviewed here, are not directly addressed in this repor.

The reports reviewed here were released during 1987-90. While we bave included the major outside review of EPA's CERCLA program, the reports that were analyzed are intended to be representative rather than exhaustive. The repors selected for review are intended to reflect the viewpoints of the major CERCL.A interest groups, e.g., Congress, environmental groups, and industry. The recommendations and conclusions set forth in these repors are generally representative of criticisms leveled against EPA's Superfund program. Although not addressed in this report, EPA also conducted a major internal review of its Superfund program (EPA 1988).

This paper does not evaluate the validity of each claim or finding contained in the reports reviewed. Nor does it specifically address issues related directly to any future CERCL.A reauthorization Rather, it should be viewed as the first step in a process to identify issues potentially relevant to DOE's implementation of its environmental restoration program. Efforts that DOE can undertake in the future include an assersment of it's environmental restoration program to further understand whether it is encountering difficulties similar to those of EPA and how potential problems could be addressed (e.g., program adjustments, legislative initiatives, etc).

\subsection{REMEDY SELECTION}

By far, the area of greatest concern, as evidenced by the studies addressing EPA's implementation of CERCLA, is that of remedy selection to clean up CERCLA sites. Principal criticisms of EPA in this area include the lack of consistency among regions when selecting remedies; an over-reliance on selecting remedies that are not permanent; a disregard for statutory requirements; a lack of common databases or information sources for remedies used; and a misplaced, disproportionate emphasis on cost A 
number of the studies also expressed the view that some form of consistent, national cleanup standards is needed.

Perhaps the most frequent theme aired by critics is that EPA is inappropriately selecting or approving remedies involving capping and/or containment, as opposed to more permanent treatment remedies. A 1990 report by a coalition of national environmental groups, Tracking Supeffund. Where the Program Stands (EDF et al 1990), states that 44\% of the Records of Decisions (RODs) finalized in 1988 merely minimized exposure through methods such as capping or fencing a site, rather than treating the wastes to eliminate the hazards of the site permanently. This echoed a similar finding by the same groups in an earlier report, Right Train, Wrong Track: Failed Leadership in the Superfund Cleanup Program (EDF et al. 1988). That repor found that $68 \%$ of the remedies selected in 1987 failed to treat the sources of contamination.

These environmental groups felt that EPA's over-reliance on containment or site restrictions was in clear contravention of explicit Congressional intent and directives to use permanent remedies to the "maximum extent practicable." Based upon an anabysis of the 1987 RODs, these groups atso concluded that EPA used inaccurate, out-of-date data to inflate the costs of treatment alternatives.

In its 1988 study of Superfund, Are We Cleaning Up? 10 Superfund Case Studies (OTA 1988), OTA also faulted EPA for failing to adequately employ permanent remedies at CERCLA sites. This problem was also highlighted in a report by Clean Sites, Improving Remedy Selection (1990), as well as OTA's 1989 report, Coming Clear: Superfund Problems Can Be Solved (OTA 1989). The Clean Sites repor recommended that EPA clearly define permanence with respect to cleanup performance and establish it as a goal of each remedy. If permanence cannot be achieved, then long-term effectiveness should be a primary criterion in the evaluation of each remedial alternative. In Are We Cleaning Up, OTA faulted EPA for claiming that leaving wastes in the ground, in groundwater, or in a landfill is a permanent remedy when, in fact, it is not

Coming Clean also specifically recommended restricting the use of pump-and-treat for groundwater beause of the uncertainty in its long-term effectiveness and because of EPA's failure to adequately communicate this uncertainty in its RODs. In general, Coming Clean recommended that RODs do a better job of commusicating and explaining any inconsistencies between the remedy selected and the clesnup criteria. OTA also recommended in Coming Clean that EPA establish a hierarchy of cleanup technologies that recognizes the environmental preference for some outcomes and types of uncertainties over others. For instance, onsite permanent destruction or recovery of hazardous substances would be favored over more impermanent remedies.

Additionally, in Are We Cleaning $U p$, OTA was critical of EPA's costing of remedies, stating that containment/land disposal decisions seldom analyzed the risk and cost of future failures, damages, and further cleanup. OTA also agreed with the conclusions of the environmental groups that EPA often selected impermanent remedies purely because they were cheaper in the short run, even though they may be more expensive over the long term.

A 1989 study conducted by the Oak Ridge National Laboratory for EPA, The Superfund Remedial Action Decision Process (Doty and Travis 1989), suppored the conclusion that EPA selected remedies principally on the basis of costs. The study is based on the review of 50 RODs from Fiscal Year 87 and their corresponding suppor documents. This study concluded that cost piayed a more important role in the selection of remedial alternatives than did risk reduction. Thirty-four percent of the RODs reviewed selected either no action or the least costly alternative other than no action, presumably because of the cost involved. Only $8 \%$ selected the most costly alternative evaluated. 
The study also found that the role of ecological risk was not significant in most EPA remediation decisions. No extensive ecological risk assessments were conducted for the RODs reviewed, and no decisions were made exclusively on ecological risk. In addition, community and state involvement generally were not the driving factor in the majority of decisions. The report concluded that compliance with applicable or relevant and appropriate requirements (ARARs), and cost, played a more significant role in remedy selection than did risk reduction.

\section{Implications for DOE}

While EPA has the authority to approve or disapprove of remedies selected for DOE CERCLA sites, DOE vill, in general, be held accountable by Congress and the public for remediation effons at its sites. In addition, since EPA has been faulted for instimuting less-than-ideal remedies in the past, DOE's remedy selection process is likely to be closely scrutinized. Accordingly, DOE should be cautious about characterizing certain remedies as permanent and, where an impermanent remedy is selected, the RODs should contain an adequate, comprehensible and defensible explanation of why a permanent remedy would be impractical or is not presently available for the site. (Lessons learned from the analysis of Superfund RODs are the subject of an EH-231 memorandum, dated December 3,1990 distributed to all program officials and field organizations.)

\subsection{CLEANUP STANDARDS}

A large number of the groups reviewing EPA's Superfund program advocated the establishment of national minimum cleanup standards for hazardous waste sites. In general, these standards would apply to all cleanup programs, regardless of the specific regulatory scheme that governed any particular sites. In Tracking Superfund, a caslition of environmental groups et al (1990) addressed the basis for advocating the use of national cleanup standards. They found that most sites have no cleanup standards for groundwater, surface water, or soil
Furthermore, where standards are set, they are based upon site-specific risk assessments rather than objective standards and criteria The environmental groups concluded that this led to great variability in cleanup levels for sites that they reviewed.

In Coming Clean, OTA recommended the cstablishment of national standards. OTA cited a number of benefits from using such standards; including ensuring that all sites, whether or not they are in the Superfund program, receive roughly equal levels of cleanup. The report stated that by establishing consistent national cleanup standards, the current inequality and inconsistency in the array of cleanops nationwide, often providing uncerain, incomplete, and ineffective protection of health and the environment, would be largely eliminated."

In their 1989 report Superfund from the Industy Pespective: Suggestions to Improve and Expedite the Superfund Remediation Process (AT\&T et al 1989), a coalition of industry groups took a slightly more cautious approach. These groups advocated the initiation of a dialogue with EPA on the development of cleanup standards.

A number of repors faulted EPA for its continued reliance on the use of "illegal" cleanup standards. The most strongly worded condemnation came from Senators Lantenberg and Durenberger in their 1989 repor Cleaning Up the Nation's Cleanup Program (Lautenberg \& Durenberger 1989). This report charged that EPA was persisting in an "illegal approach to groundwater cleanup standards" and that EPA was attempting to "irstitutionalize the noncompliance with the legal mandate to apply the most stringent standards to groundwater cleanup." The environmental groups in Tracking Superfund further alleged that EPA was not taking adequate steps to clean up groundwater contamination and that, in many instances, EPA was simply writing off contamination of an aquifer as unimporant

\section{Implications for DOE}

While differences in approach exist amongst the EPA regions, consistency in the process of selecting 
cleanup standards for environmental restoration activities across the DOE comples will be extremely imporant to the Department, especially when the environmental restoration program becomes subject to increased scrutiny. This would include ensuring that consistent documented assumptions are used in all risk assessments that may be used to set site-specific cleanup levels. Deviations from generalty accepted cleanup levels shouid also be explained and documented in the ROD. The use of information systems and other tools to make site specific information available to DOE headquarters and across the DOE compler will be helpful in setting cleanup levels that are more consistent throughout DOE

\subsection{USE OF TECHNOLOGY}

Both EPA and DOE have recognized that the development of new and innovative technologies is essential to cleaning up of hazardous waste in an efGicient and cost-effective manner. EPA has established its Superfund Innovative Technology Evaluation (SITE) program and has taken other steps in an attempt to encourage the demonstration and use of new technologies. DOE has established its Research, Development, Demonstration, Testing, and Evaluation (RDDT\&E) program in the Office of Technology Development (OTD) to develop and transfer promising new technologies to address its hazardous and radioactive waste problems.

A number of outside groups reviewed and commented on EPA's use of technology. Senators Lautenberg and Durenberger sounded a fairly cautious note about EPA implementation of new technology. They suggested that any new innovauve technology must have a substantiated probability of success before it is selected for a site. They also recommended that EPA establish a centralized technology clearinghouse to facilitate access to technology information.

In Are We Cleaning Up, OTA faulted EPA for its failure to identify and implement new technologies. OTA claimed that many good, permanently effective waste treatment technologies are on the market bet, too often, are not fully examined or are not selected for use. OTA also said the paucity of reliable, accurate information about technologies makes selection difficult it cited examples of unreliable cost estimates for new technologies, and cases where assessment of actual implementation of new technologies was poor or nonexistent In addition, OTA faulted EPA for selecting technologies for site remediation that were still in the SITE program, an indication to OTA that the technology has not yet been proved.

In Coming Clean, OTA also recommended that EPA better define the mission of the SIIE program. OTA suggested the mission of the SIIE program should be to push the frontiers of cleanup technology. According to OTA, the SITE program should focus less on technologies that already have extensive private sector support and more on the demonstration of truly innovative technologies that seem too risky or uncerain for the private marketplace and those that have a chance for major improvement in cleanup technology effectiveness and risk reduction. OTA additionally suggested that $R \& D$ efforts be focused on groundpater cleanup.

The environmental groups (1990) fauted EPA's use of cenain technologies despite data showing them to be ineffective; promising new technologies, such as bioremediation, were misapplied or not used where appropriate; treatment trains, a series of technologies to address specific problems, were generally not considered; and ueatability studies were seldom done before a remedy was selected. In Right Train, Whong Track, the same environmental groups claimed that EPA frequently eliminated technologies from consideration solely because of $\cos \mathrm{L}$

Clean Sites, in its 1989 report Making Superfund Work, recommended the increased use of treatabiity studies where there is uncertainty about the potential performance of specific technologies. The organization also suggested that EPA establish boards of technical experts at the headquarters and regional levels to belp assess technical questions 
that are difficult to resolve. In addition, the report stated that easier access to all RODs for Superfund sites could facilitate the selection of appropriate technologies for new sites.

\section{Implications for DOE}

The development and deployment of new technologies is a vital component of DOE's environmental restoration program. Information about new and developing effective technologies will need to be accessible to those in the field who are responsible for making initial remedy selection decisions. This activity should include developing an adequate amount of data to show the effectiveness of each technology. In addition, a technology database describing what exising technologies can do to solve DOE's cleanup problems would be valuable.

\subsection{MEASURES OF PERFORMANCE}

A number of groups were critical of EPA's efforts to measure its performance in remediating Superfund sites. While these groups generally ackoowledged that EPA was largely driven by statutory deadlines and other requirements, they felt that a better system for gauging performance couid he developed Responding to desdines set by CERCLA, EPA has normally evaluated its performance by the number of studies or other activities initiated.

In Making Superfund Work, Clean Sites suggested that EPA track measures of success that focus on achievements or outputs, rather than on inputs, such as studies initiated or under way. This group urged that easily understood information on Superfund progress be made available to the public.

Both OTA, in Coming Clean, and the environmental groups, in Right Train, Wrong Track, also suggested developing a system that measures performance based on work completed rather than on work initiated Right Trair, Wrong Track noted that EPA's practice of pushing certain activities at the end of fiscal years atso has the potential to lead to bad decision making.

\section{Implications for DOE}

DOE is not driven by all of the same stantory requirements as EPA's Superfund program. However, like Superfund, the DOE environmental restoration program will ultimately need to eliminate unacoptable risk to buman health and the environment at sites under its purview. Performance measures that reflect this type of risk reduction need to be developed for Departmental use.

DOE is at the front end of its environmental restoration program and has the unique opportunity to explore various options for establishing valid performance criteria for the program. Such criteria could incorporate work completed, health and ecological risks reduced, and other costs avered.

\subsection{ORGANIZATIONAL ISSUES}

EPA has a very decentralized organizational structure. It consists essentially of a headquarters office in Washington, D.C, and ten largely autonomous regional offices. The headquarers office is responsible for, among other things, developing and coordinating policy. National program policy is developed in headquarters by two offices: 1) the Office of Solid Waste and Emergency Response, which includes both the Office of Emergency and Remedial Response and the Office of Waste Programs Enforcernent, and 2) the Office of Enforcement and Compliance Monitoring. Each regional office is run by a regional administrator who reports directly to the EPA administrator. Within each region is a hazardous waste division, which often houses both CERCLA and RCRA programs.

A number of groups have charged that EPA's decentralized decision-making process has led to a lack of consistency in CERCLA decisions made by the regional offices and has given the regions too much flexibility, causing them to avoid the stringent requirements mandated by CERCLA. On the other hand, some groups, especially those representing industry, view this flexibility as positive. 
In Coming Clean, OTA urged EPA headquarters to strengthen its direction and oversight of regional offices. OTA faulted EPA for "excessive regional autonomy' and cited EPA's own study showing that $20 \%$ of the 1988 RODs did not follow agency guidelines for remedy selection. The report recognized that the flexibility the regions want competes vith national consistency.

Senators Lautenberg and Durenberger also raised this issue in the 1989 report Cleaning Up the Nation's Cleanup Program. They urged EPA headquarters to exert strong sational leadership in the remedisl program. They also recommended that EPA improve its regionally provided data describing Superfund activity.

Clean Sites, in their 1989 study Moking Superfund Work, recommended that EPA continue to delegate site-specific decision making to the regions, but that the regional administrators be made directly accountable to a designated headquariers official Clean Sites also recommended that regional decisions relating to site cleanup technology be subject to a limited and expedited discretionary appeal to headquarters in order to ensure national consistency.

The industry coalition that produced Superfund from the Indusiry Ferspective recognized the lack of consistency in the implementation of basic CERCLA goals and policies among the various EPA regions (AT\&T et al 1989). Despite this recognition, the coalition advocated turning more responsibility over to private parties to carry out the cleanup activities. They also recommended giving regional EPA officials greater authority to negotiate with the private sector, within established headquarters guidelines.

\section{Implications for DOE}

DOE, with ils organizational structure of headquarters, operations and field offices, is somewhat similar to EPA. It is possible that DOE may encounter many of the same difficulties engendered by such a decentratized structure. At present, however, DOE has taken steps through the establishment of the headquarters Office of Environmental Restoration and Waste Management to move toward more centralized control and revicw of environmenial restoration actions. In doing so, DOE has positioned itself to implement actions that could help ensure consistency and efficiency in its CERCLA work Such actions will need to include clearly defining the roles and responsibilities of the various headquarters offices and fiejd offices, establishing easily understood regulatory and programmatic guidance for carrying out various CERCL.A actions, and reviewing key CERCI_A documents and decisions complex-wide to detea any developing policy differences and inconsistencies.

DOE may also be impacted by the effects of EPA's decentralized organization, since EPA's regional offices, with corresponding differences in approach, will continue to have oversight over DOE's environmental restoration activities. This would be further complicated in cases where envirotmental restoration activities are subject to oversight by the states.

\subsection{STREAMRINING OF THE CERCLA PROCESS}

Emphasizing what they felt was the excessive amount of time and money needed to carry out CERCLA remediations, a number of reports, including those done by CH2M Hill (Dehn 1989), the industry coalition and Senators Lautenberg and Durenberger, strongly advocated that EPA implement procedures that would streamline the Superfund process, especially at the remedial investigationfleasibility study (RVFS) stage. These reports suggested a number of steps that could be implemented to achieve this goal. In fact, EPA has conducted a number of studies and made recommendations to belp streamline the process.

In a 1989 report (Dehn 1989), CH2M Hill, a major environmental consulting group, made sev. eral observations and recommendations to EPA in this arez. First, EPA should recognize that uncerainty is an unavoidabie component of 
Superfund work and should therefore avoid the tendency to over-study a site. $\mathrm{CH} 2 \mathrm{M}$ Hill suggested the use of the observational approach (a streamline approach to conducting an RI/FS) to deal with the uncertainty. Second, EPA should implement obvious remedial steps early in the process. To help achieve this, the ROD should be made a more flexible document to enable the parties to respond to changing or newly discovered circumstances with a minimum amount of red tape. Third, the RI/FS should be viewed as a technical decision document rather than primarily a legal instrument. This would focus the documentation on the problems at hand rather than on simply trying to build a legal case.

To facilitate the CERCLA process, the industry coalition in Superfund from the Indusay Perspective, advocated the development of a less adversarial relationship between EPA and potentially responsible paries (PRPs). This coalition encouraged early consulting between industry and EPA, reducing the universe of remedial alternatives considered and evaluated, implementing interim measures, and establishing a national clearinghouse of remedies.

In Cleaning Up the Nation's Cleanup Program, Senators Lautenberg and Durenberger urged EPA to continue to push streamlining effors for the CERCLA process. They also recommended that EPA consider beginning actual cleanup work, consistent with a long-term remedy, during the RI/FS stage.

Implications for DOE

As DOE progresses through the RI/FS process at most of its CERCLA sites, the application of viable streamlining measures needs to be fully considered. In cooperation with EPA, DOE should pursue the identification of potentially feasible streamlining activities that satisfy regulatory requirements, i.e., remedies that protect human health and the environment. Such an effort also will require close coordination and involvement of DOE's field offices and contractors, as well as affected states, in order to successfully develop a streamlined approach that is readily acceptable to all partics. The Department has taken initial steps in this direccion as evidenced in the Headquarters DOE (EH-231) memorandum dated October 23, 1990, subject: Streamlining Remedial Investigations/Feasibility Studies.

\subsection{STAFF UTILIZATION AND DEVELOPMENT}

Many groups identifed the hiring, training, and retention of qualified staff as a key problem in EPA's CERCLA program. Many observers of the Superfund program have noted that EPA's inability to retain and train key staff has greatly hindered its implementation of Supertund The groups reviewing the Superfund program have made a number of suggestions to address this problem.

In its report Superfund: Improvements Needed in Work Force Management (GAO 1987), GAO made a number of observations and recommendations: a survey of EPA Supertund employees showed that $80 \%$ of these employees worked in units they believed were understaffed; employee turnover in key positions has adversely impacted the Superfund program; EPA lacks productivity measures to gauge how efficiently it is using its Superfund staff Like many other groups, GAO recommended that EPA implement plans and policies for improving Superfund training.

In Coming Clean, OTA suggested a permanent activity in EPA's Superfund office to improve the performance of the national cleanup work force, both in government and in the private sector. OTA further suggested that to add continuity to the remediation of specific sites, one manager should be made responsible for a site from the time it enters the Superfund program until it is completely remediated.

Senators Lautenberg and Durenberger credited EPA for recent steps it has taken to address this problem, but said that EPA should institutionalize its Superfund training and retention programs and expand these programs to all relevant staff at EPA 
In addition, the Senators suggested that EPA somebow link participation by staff in Superfund training programs with a commiument to stay with the Superfund program for a designated period of time.

The industry coalition (1989) made similar recommendations. They called for EPA to seek to obtain multi-year commitments from its key staff and to develop various incentives to retain its Superfund employees. In Making Superfund Work, Clean Sites also recommended increasing the training opportunities for Superfund staff as well as opgrading the remedial project manager (RPM) positions in the regional offices. Finally, $\mathrm{CH} 2 \mathrm{M}$ Hill suggested that EPA make an effort to employ qualified RPMs with ongineering backgrounds.

\section{Implications for DOE}

Training and retaining key environmental restoration staff is also essential to the long-term success of the Department's environmental restoration program. Investments made in this area are likely to pay dividends in consistency of program decisions and a streamlined environmental restoration process for DOE. Departmental goals might include attracting highly qualified staff to its environmental restoration program and avoiding the excessively high turnover rates that EPA bas experienced in the past

The groups reviewing EPA's Superfund program made numerous suggestions for addressing this problem. EPA has implemented a number of programs aimed at improving employee training and retention rates. Consideration should be given to monitoring these EPA programs; identifying those that are successful; applying them at DOE when feasible; and exploring other options, such as exchange programs with private industry and other federal agencies, that would enhance the quality of DOE's environmental work force.

\subsection{USE OF CONTRACTORS}

EPA relies heavily upon contractors to carry out much of its Superfund work This work includes assistance in drafting guidance and policy documents, carrying out site characterization and drafting related documents, and conducting actual site remediation work This reliance on the use of contractors is an outgrown of both the sheer amount of work to be done and a move by the federal government during the past 10 years to use contract resources to the fullest extent possible. As one might expect in a high profile area like Superfund, EPA has been sharply criticized by a number of groups for its over-reliance on contractors, as well as for its management of contractors and associated costs.

The U.S. Serate Committee on the Budget (1990) cited four major criticisms of EPA's use of contraciors: 1) failure to assure that contractors perform the work they are contracted to do; 2) failure to control contractor costs and fees; 3) use of an inefficient and expensive contracting mechanism; and 4) inappropriate use of contractors to perform inherently governmental functions.

\section{In Superfund Contracts: EPA Needs to Control} Contractor Costs (GAO 1988), GAO charged that EPA has not sufficiently monitored, controlled, and challenged contractor expenditures and professional bour usage for remedial studies. GAO recommended that EPA improve its oversight of remedial contracior performance and expenditures by taking appropriate actions to challenge and deal with questionable costs. GAO also recommended that the EPA administrator affirm his commitment to cost concrol on remedial contracts by communicating the importance of balancing timeliness, quality, and costs.

In Coming Clean, OTA recommended that EPA reduce its dependence on contractors, expand its 
work force to carry out its Superfund responsibilities, and make increased use of the national laboratories. Senators Lautenberg and Durenberget in Cleaning Up the Narion's Cleanup Program, recognizing recent steps EPA has taken to enhance its oversight of contractor activities, stated that EPA should push ahead with these reforms and assess their impacts.

The Senate Budget Committee in its report Management of Superfund, stated that EPA makes heavy use of a contract mechanism, cost-plus award fee that does not create incentives to control costs. Under this system, the contractor is entitled to reimbursement for all allowable costs, plus a base profit Because the contractor will receive a profit regardless of cost, the contractor has little incentive to hold down costs. The committee urged EPA to monitor contractor performance more strictly and to move to fixed priced contracting, giving the contractor a clear incentive to deliver on-time and within budget

On the other hand, CH2M Hill, a major EPA contractor argued for more flexibility in EPA's contracting mechanisms. It claimed that uncertainty usually exisıs for many Superfund projects and that change orders in contracts should be expected. CH2M Hill urged greater efficiency in EPA's contract and procurement procedures and said contracting and procurement officers should adopt a "can do" attitude, rather than ofien being hindrances. $\mathrm{CH} 2 \mathrm{M}$ Hill suggested that site progress goals shouid be put into these officials' performance standards to encourage greater cooperation.

Questions have also been raised regarding potential conllict of interests of EPA's contractors. In its 1989 report Superfund Contract: EPA's Procedures for Preventing Conflicts of Interest Need Strengthening (GAO 1989), GAO found that EPA's conIict of interest system contains weaknesses that hinder jts ability to adequately ensure that contractors are adtering to EPA's policy. GAO suggested a number of steps to strengthen EPA's procedures, including directing contracting officers to document actions taken to resolve conflicts, providing contractors and contracting officers additional information on how to avoid conflicts, and including conflict of interest issues as part of its review of contractors' performance.

\section{Impllantions for DOE}

Based on EPA's experiences with Superfund, there is little doubt that at some point DOE's use and mositoring of environmental restoration contractors will be subjected to external scrutiny. Accordingly, lessons learned from the use of contractors in the Superfund program indicate a need for an effective mechanism to ensure the integrity of the environmental restoration program relative to the use of contractors, specifically, to protect against contractor conflict of interest (or perception of conflict of interest), wasteful spending, and the inappropriate or questionable use of contractors. Allegations of wasteful and ineffective spending in DOE's eqvironmental restoration program could seriously damage DOE's relationship with Congress, regulators, and the public and coujd undermine the ultimate success of the program.

\subsection{SUMOMARY}

Numerous outside groups thave reviewed and critiqued EPA's implementation of its Superfund program These groups have identified many shortcomings and mistakes made by EPA during the 10 year life span of Superfund. While a number of the conclusions and recommendations made by these groups may lack substance or may be inconsistent with each other, they do generally indicate a number of generic issues and concerns with the implementation of the CERCLA program, including remedy selection, appropriate cleanup standards, the development and use of new and innovative technologies, establishment of performance criteria for program evaluation, the use and management of contractors, streamlining of the Superfund process, management and development of staff, and organizational issues. Since DOE is generally at the beginning stages of its environmental restoration program, it is uniquely positioned to apply the lessons learned from EPA's Superfund program and, 
thus, to forgo the pitfalls EPA has experienced over the past ten years.

Considering the magnitude and scope of the effort abead, there is little doubt that DOE's environmental restoration program will be sub. jected to reviews and critiques by many of the same groups over the nerr several years. It sbould also be expected that, given the nature of the political environment, many of these reviews will be somewhat critial. DOE may not be able to avoid this, however, the Departinent should not be driven solely by the motivation to avoid negative publicity. Consistent with the CERCLA mandate, the department's goal is and should remain to carry out its environmental restoration in the most costeffective manner that maximizes protection of buman health and the environment and complies with applicable statutes and regulations.

DOE should be cognizant of and take steps to incorporate lessons learned from EPA's experience in an effort to minimize potentially related problems in its environmental restoration program. DOE needs to understand the Superfund issues raised by these outside groups and their relevance to its environmental restoration program and to take steps to avoid encountering the same problems. This effort should be part of an overall program to identify and address issues that present apparent obstacles to DOE's implemenuation of its CERCLA responsibilities. Many of the issues raised by this report extend beyond the purview of the Office of Environmenta) Guidance and should be addressed jointly by all of the DOE elements that have environmental restoration responsibilities. The Office of Environmental Guidance has compiled reviews and critiques of the EPA Superfund program by various outside groups. in addition, PNL has prepared this repor. Both are initial steps toward identifying lessons learned and sharing them with the DOE environmental restoration community.

\section{REFERENCES}

Amerian Telephone and Telegraph Company, et al 1989. Superfund from the Industry Perspective: Suggestions to Improve and Expedite the Superfund Remediation Process. Wasbington, D.C.

Clean Sites, Inc, 1990. Improving Remedy Selection: An Explicir and Inseracive Process for the Superfund Program. Washington, D.C.

Clean Sites, Inc 1989. Making Superfund Work Wasbington, D.C.

Comprehensive Environmental Response, Compensation, and Liability ACt (CERCLA) of 1980. 42 U.S.C 9601 et seq., Public Law 96-510, as amended.

Committee on the Budget, United States Senate. 1990. Management of Superfund. Washington, D.C.

Dehn, W. I 1989. Lener to Lew Crampton, U.S. Environmental Protection Agency. DIS227.33.10, $\mathrm{CH} 2 \mathrm{M}$ Hill, Reston, Virginia.

Doty, C B., and C. C. Travis. 1989. The Superfund Remedial Action Decision Process. ORNLM-780, DE89 010160, Oak Ridge National Laboratory, Oak Ridge, Tennessee.

Environmental Defense Fund et al. (EDF). 1990. Tracking Superfund: Where the Program Stands. Washington, D.C.

Environmental Defense Fund et al (EDF). 1988. Right Train, Wrong Track: Failed Leadership in the Superfund Cleanup Program. Washington, D.C.

Environmental Protection Agency. 1988. A Management Review of the Superfund Program. Washington D.C. 
Lautenberg, F. R, and D. Durenberger. 1989. Laurenberg-Durenberger Repon an Superfund Implementarion: Cleaning Up the Narion's Cleanup Pro gram. U.S. Senate Subcommittee on Superfund, Ocean and Water Protection, Washington, D.C.

U.S. Congress, General Accounting Office. 1989. Superfund Contracts: EPA's Procecturer for Preventing Conflicts of Interest Need Strengthening. GAO/RCED_89-57, Washington, D.C.

U.S. Congress, General Accounting Office 1988 Superfund Contraess: EPA Needs to Control Contractor Costs. GAO/RCED-88-182, Washington, D.C
U.S. Congress, General Accounting Office. 1987. Superfund: Improvements Needed in Work Force Management. GAO/RCED-88-1, Washington, D.C.

U.S. Congress, Office of Technology Assessment. 1989. Coming Clear: Superfund Problems Can Be Salved. OTA-ITE-443, U.S. Government Printing Office, Washington, D.C

U.S. Congress, Office of Technology Assessment. 1988. Are We Cleaning Up? 10 Superfund Case Studies. OTA-ITE-362, U.S. Government Printing Office, Washington, D.C 


.




\section{DISTRIBUTION}

No. of

Copies

\section{OFFSITE}

12 DOE/Office of Scjentific and Technical Information

1 T.T. Traceski

U.S. Department of Energy

EH-231, GA-076 Forrestal Building

1000 Independence Avenue, S.W.

Washington, DC 20585

\section{ONSITE}

29 Pacific Northwest Laboratory

C.W. Abrams (2)

W.E. Fallon

C.A. Geffen

R.E. Gephart

J.F. Keller

T.L. Kuusinen

A.M. Lesperance

J.A. Powell (2)

R.D. Quinn

M.R. Siegel (10)

D.R. Simpson

E.J. Wilczynski

Publishing Coordination

Technical Files (5) 
•

$-$ 